\author{
EISSN:2706-7920 ISSN: 2077- 4435 \\ DOI: 10.36632/csi/2021.10.1.21 \\ Journal homepage: www.curresweb.com \\ Pages: 226-233
}

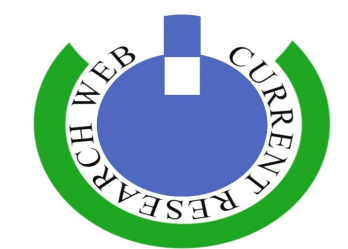

\title{
Effect of Dietary Supplementation of Mananoligosaccharide and $\beta$-Glucan on the Performance and Feed Utilization of Nile Tilapia Fingerlings
}

\author{
Hanan A. Abo-State, M. M. El-Monairy, Y. A. Hammouda and H. M. A. Hassan \\ Animal Production Department, National Research Centre, Cairo, Egypt
}

Received: 10 February $2021 \quad$ Accepted: 25 March $2021 \quad$ Published: 30 March 2021

\begin{abstract}
Background and Objective: Prebiotics feed additives can be used as functional feed and applied in aquaculture for improving growth performance and feed utilization. Feeding trail was performed to investigate the effect of different levels of commercial prebiotic (Aqua-Immuostim ${ }^{\odot}$ ) contain Mananooligosaccharide (MOS) and $\beta$-glucan on the performance and feed utilization of Nile tilapia (Oreochromis niloticus) fingerlings. Methodology: Three hundred of Nile tilapia $\left(4.12 \mathrm{~g} \mathrm{fish}^{1}\right)$ were randomly allocated into 4 treatments. Treatments were performed in 12 aquaria ( $25 \mathrm{fish} /$ aquarium). Nile tilapia were fed basal diet $\left(30.36 \%\right.$ crude protein, $3879 \mathrm{kcal}$ gross energy $\mathrm{kg}^{-1}$ diet) with different levels of prebiotic $\left(0.0,2,4\right.$ and $6 \mathrm{~g} \mathrm{~kg}^{-1}$ diet). Fish were fed diets twice daily for 56 days. Results: The best values of the final body weight, body weight gain, feed conversion ratio and specific growth rate were obtained with all treatments supplemented with MOS and $\beta$-glucan compared with the control group. The best values of feed conversion ratio (FCR), protein efficiency ratio (PER), Protein productive value (PPV) and Energy Retention (ER) were observed in groups fed on diets supplemented with MOS and $\beta$-glucan at 2 and $4 \mathrm{~g} / \mathrm{kg}$, followed by diet supplemented with $6 \mathrm{~g} / \mathrm{kg}$, and the worst values of FCR, PER, PPV and ER were observed with the control group. No significant difference was detected among all treatments in body composition. Conclusion: Overall, this study revealed that MOS and $\beta$-glucan inclusion in Nile tilapia diets could be more beneficial effects on the growth and utilization of feed. In the current study, the optimal level of the commercial MOS and $\beta$ glucan in Nile tilapia fingerlings diets is $2 \mathrm{~g} / \mathrm{kg}^{-1}$.
\end{abstract}

Keywords: prebiotic, Nile tilapia, performance, feed utilization, MOS and $\beta$-glucan.

\section{Introduction}

Using the best feeding system can have a beneficial effect on optimizing profit that is the first goal of commercial aquaculture (Abo-state and Tahoun 2017). Also, capable fish to resist diseases can reduce of the posterior cost of therapy and total production costs would be reduced (Ringø et al., 2010). It is just now a deftly-documented truth that there is a clear relation between the nutrition and health status of fish. Application of intensification aquaculture to meet market request causes lead to raise the possibility of the disease breakout (Hoseinifar et al., 2015). Several feed additives have been used to enhance growth performance and health status of fish. More natural feed additives like probiotics and prebiotics found that positive effect for enhancing the immune response, feed efficiency, and performance of fish (Kesarcodi et al., 2008, Mehdi and Mojtaba, 2009, Guardiola et al., 2016 and Mohsen et al., 2016). Beta-glucan and MOS are naturally polysaccharides found in the cell wall of yeast, fungi and algae and used in fish nutrition as prebiotics. Prebiotics prompt growth performance, enhance nutrient utilization and gut growth and modify innate and acquired immunity responses (Andrews et al., 2009, Yousefian and Amiri, 2009, Geraylou et al., 2013, Torrecillas et al., 2014 and Selim and Reda, 2015). Prebiotics are beneficially affects the host by selectively stimulating the growth and metabolism of health-promoting bacteria out of prebiotics fermentation (Gibson and

Corresponding Author: Hanan A. Abo-State, Fish Nutrition Lab, Animal Production Department, National Research Centre, Cairo, P.O. Box 12622 Dokki, Giza, Egypt.

E-mail:hanan_abostate@yahoo.com, ORCID ID: 0000-0002-6659-0635.

http://livedna.org/20.15328, Scopus ID: 56427888500 
Roberfroid, 2004, Ringø et al., 2010 and Abo-state et al., 2017) gut microbiota (Zhou et al., 2010) resistance against pathogenic bacteria (Talpur et al., 2014) and immuneparameters (Guerreiro et al., 2016).

Several studies have been carried out in fish to evaluate one prebiotic such as inulin (Cerezuela et al., 2013 a,b), Mannan-oligosaccharides (MOS) (Torrecillas et al., 2013) and fructooligosaccharides (FOS) (Hoseinifar et al., 2017 and Guerreiro et al., 2018). Azeredo et al., 2017 found that supplementation of FOS in fish diets improved growth performance, feed utilization and immune responses. Addition of 1, 2 or $3 \mathrm{~g}$ FOS $/ \mathrm{kg}$ feed enhanced performance, enzyme activities, feed utilization and immune response of Lateolabrax japonicas (Wang and Li, 2020). Therefore, the current study aimed to assess the effects of different levels of MOS and $\beta$-glucan as a natural prebiotic on growth, utilization of feed and body composition of fingerlings Nile tilapia (O. niloticus).

\section{Materials and Methods}

\subsection{Fish and culture facilities}

Monosex (male) Nile tilapia fingerlings $\left(4.19 \mathrm{~g} \mathrm{fish}^{-1}\right)$ were obtained from a commercial tilapia hatchery at Kafr El Sheikh Governorate, Egypt. Fish were randomly distributed in triplicate into four treatment groups in the Fish Nutrition Laboratory, National Research Centre, Egypt. Treatments were performed in twelve glass aquaria $\left(60 \times 30 \times 40 \mathrm{~cm}^{3}\right)$ at a rate of 25 fish /aquarium. The experimental fish were acclimated to the culture system for 2 weeks. Initially, fifty fish were randomly collected and the average initial weights were recorded then frozen at $-20^{\circ} \mathrm{C}$ for whole body analysis. Water temperature, dissolved oxygen and $\mathrm{pH}$ were adjusted around $26.5 \mathrm{C}^{\circ}, 6 \mathrm{mg} / \mathrm{L}$ and 7.5 respectively in all treatments and monitored daily.

\subsection{Test diets and feeding regime}

A basal diet was formulated to contain $(30.36 \%$ crude protein, 5.79 ether extract, 6.7 crude fibers, $14.2 \%$ ash, and $3879 \mathrm{Kcal}$ gross energy $\mathrm{kg}^{-1}$ diet). A commercial prebiotic product (AquaImmuostim $^{\circ}, 1 \mathrm{~kg}$ contains: Mannan-oligosaccharide and $\beta$-glucan $250 \mathrm{~g}$, Vitamin C $25 \mathrm{~g}$ and citric Acid (\%90) $50 \mathrm{~g}$ ) was added to the basal diet to represent the levels of 0.0 (control), 2, 4 and $6 \mathrm{~g} \mathrm{~kg}^{-1}$ diet. Fish were fed their respective diets twice a day (at 8 am and $13 \mathrm{pm}$ ) for 56 days (at $5 \%$ of their body weight for the first 2 weeks then $4 \%$ for the last six weeks). The average weight of fish was recorded every 14-day intervals, and the daily rations were readjusted accordingly.

\subsection{Chemical analysis of diets and fish}

The tested diet and fifteen fish collected from each treatment at the beginning and at the end of the feeding experiment were analyzed for moisture content, protein, fat and ash according to the standard methods of AOAC (2006).

\subsection{Calculations of fish performance}

The growth performance and feed utilization efficiency were calculated as following:

Weight gain $(\mathrm{WG})=$ final weight - initial weight .

Specific growth rate $(\mathrm{SGR})=100\left(\ln \mathrm{W}_{2}-\ln \mathrm{W}_{1}\right) / \mathrm{T}$

where $\mathrm{W}_{1}$ and $\mathrm{W}_{2}$ are the initial and final weight, respectively, ln represent Natural logarithm and $\mathrm{T}$ is the number of days in the feeding period.

Feed conversion ratio $(\mathrm{FCR})=$ dry feed intake $(\mathrm{g}) /$ fish live weight gain $(\mathrm{g})$.

Protein efficiency ratio $($ PER $)=100($ weight gain $(\mathrm{g}) /$ protein intake $(\mathrm{g}))$.

Protein productive value $(\mathrm{PPV})=100($ protein gain $(\mathrm{g}) /$ protein fed $(\mathrm{g}))$.

Energy Retention $(\mathrm{ER})=$ Retained energy in carcass $(\mathrm{Kcal}) /$ energy intake $(\mathrm{Kcal}) \times 100$.

\subsection{Statistical analysis}

All data were subjected to one-way analysis of variance (ANOVA) at a 95\% confidence limit, using SPSS software, version 16 (SPSS, 2007). Duncan's Multiple Range (Duncan, 1955) test was used to compare means when F-values from the ANOVA were significant $(\mathrm{P}<0.05)$. 


\section{Results and Discussion}

Mean values of initial body weight (IBW), final body weight (FBW), weight gain (WG) and specific growth rate (SGR) of Nile tilapia fingerlings fed various levels of MOS and $\beta$-glucan are shown in Table (1). The IBW was almost similar in all groups without differences $(\mathrm{P}<0.05)$. Supplementing MOS and $\beta$-glucan in Nile tilapia fingerlings diet resulted in significant improvement in FBW, WG and SGR $(\mathrm{P}<0.05)$ compared to those fed the control diet without supplementation.

The results of feed utilization parameters, feed intake (FI), feed conversion ratio (FCR), protein efficiency ratio (PER), protein productive value (PPV) and energy retention (ER) are shown in Table (2). Results observed enhancing effect of MOS and $\beta$-glucan supplementation on feed efficiency. There were, differences $(\mathrm{P}<0.05)$ of FCR, PER, PPV and ER among the treatments. The superior values of FCR, PER, PPV and ER were observed in groups fed on diets supplemented with MOS and $\beta$-glucan at 2 and $4 \mathrm{~g} / \mathrm{kg}$, followed by diet supplemented with $6 \mathrm{~g} / \mathrm{kg}$, and the worst values of FCR, PER, PPV and ER were observed with the control. No differences $(\mathrm{P}>0.05)$ were observed among various levels of MOS and $\beta$-glucan on FCR, PER, PPV and ER.

The results of whole body composition of Nile tilapia are shown in Table (3). Supplementation of MOS and $\beta$-glucan did not significant affect $(\mathrm{P}>0.05)$ in body composition (Dry matter (DM), Crude protein (CP), Ether extract (EE) and Ash) of Nile tilapia.

These results are agreement with the previous results of several studies that reported improvement in growth performance of fish fed diet supplemented with prebiotics (Ringø et al., 2014 and Romero et al., 2014). Addition of prebiotic improved growth performance of hybrid striped bass (Gatlin and Li, 2004). Mazurkiewiez et al. (2008) addition different levels (0.0, 1, 2 and 3g/kg feed) of a commercial prebiotic (Fermacto) to carp fry diets improved $(\mathrm{P} \leq 0.05)$ body weight compared with the control. Also, the higher improvements of SGR, FCR, PER and coefficients of feed protein retention have been obtained in the treatment with $3 \mathrm{~g}$ prebiotic $/ \mathrm{kg}$ of feed. Similar results, fed rainbow trout diet containing $2 \mathrm{~g} \mathrm{Kg}^{-1}$ MOS improved growth performance and feed utilization compared with those fed on the basal diet (Staykov et al., 2007 and Grisdale-Helland et al., 2008). Staykov et al. (2007) reported that fed rainbow trout diet supplemented with $2 \mathrm{~g} \mathrm{Kg}^{-1} \mathrm{MOS}$ improved lyzozyme activity. Dietary $2 \mathrm{~g} \mathrm{Kg}^{-1}$ MOS remarkably improved the growth and feed utilization in gilthead sea breem (Gültepe et al., 2011). Ebrahimi et al. (2012) studied the effect of dietary MOS on feed efficincy, performance, immunity stimulation and body composition analysis of the Common carp fingerlings (11.12g) different levels $\left(0,0.5,1,1.5\right.$ and $2.5 \mathrm{~g} \mathrm{Kg}^{-1}$ diet).

Results indicated that addition of MOS from 1 to $1.5 \mathrm{~g} \mathrm{Kg}^{-1}$ improved feed efficiency and growth performance. Ganguly et al. (2013) found that MOS can be used as alternative to growth promoters with combination with organic acid to achieve good health and growth performance. These improvements related to improved nutrients utilization due to changes in digestive enzymes activity and thus enhance performance (Merrifield et al., 2010 and Anguiano et al., 2013). Higher growth performance of Caspian roach (Rutilus rutilus) and blunt Shout breum (Megalobrameambly cephala) fed prebiotic was correlated with enhanced digestive enzyme activity (Soleimani et al., 2012 and Wu et al., 2013). Talpur et al. (2014) reported that dietary supplemented with $2 \mathrm{~g} \mathrm{~kg}^{1} \mathrm{MOS}$ for three month increased lyzozyme activity of Snakehead (Channa striata). Incorporation of $1 \mathrm{~g} / \mathrm{kg}$ MOS was suggested to enhance growth and feed utilization of Sea bass (Dicentrarchus labrax) (Salem et al., 2016). The improvement of growth performance may be related to several factors, such as improved gut morphology or modifications in intermediary metabolism, improved digestive enzymatic activity (Hoseinifar et al., 2013 and Ringø et al., 2016). Utilization of nutrients mainly depends on the activities of digestive enzyme in alimental tract which reflects on feed efficiency and nutrient utilization (Fountoulaki et al., 2005). Furthermore, short-chain fatty acids (SCFA) produced in prebiotics fermentation reducing gut $\mathrm{pH}$ and provide nutrients for the fish which improved growth, disease resistance and immunity (Guerreiro et al., 2018). Improved digestive enzymes activities that were detected in fish fed prebiotics may be a reason for bacterial digestive enzyme production (Hu et al., 2019).

Furthermore, Cechim et al. (2012) reported that MOS supplementation (0.2, 0.4 and $\left.0.8 \mathrm{~g} \mathrm{~kg}^{-1}\right)$ in Nile tilapia diet $(12.62 \mathrm{~g})$ did not show a positive effects on Juvenile Nile tilapia growth. Dietary supplementation of MOS at various levels did not have an effect on moisture and crude ash content of 
Japanese flounder (Paralichthys olivaceus) (Ye et al., 2011), in contrast reducing body fat was found of fish fed MOS and inulin in sherpsnout Sea bream (Diplodus puntazzo) (Apperbossard et al., 2013). General it seems that the high body protein content reveals the ingested feed was converted extra beneficially into synthesis protein in turn enhance growth performance (Kumar et al., 2018).

Contradictory results of prebiotic may be imputed to the addition level and duration of experiment (Dawood and Koshio 2016 and Hoseinifar et al., 2017). Munir et al. (2016) revealed a positive effect of dietary prebiotic and probiotic as feed supplements for Snake head (Channa striata) fingerlings. Effects prebiotic depend on many items such as addition level and fish species, dietary supplementation of different feed additives like prebiotics in low level have been reported to enhance growth performance feed utilization and immunity fish (Ganguly and Prasad, 2012).

Studies focused on effects of using $\beta$-glucan in fish diets reported that $\beta$-glucan improved performance, utilization of feed and immune response (Brogden et al., 2012, Dobšíková et al., 2013, Al-Faragi 2014, Falco et al., 2014 and Jung- Schroers et al., 2016). Gu et al. (2011) found that supplementation of $0.15 \% \beta$-glucan and $0.1 \%$ MOS improved specific growth rate values compared with the control $(P<0.05)$ and had the best effects on enhancing disease resistance of sea cucumber (Apostichopus japonicas). Kühlwein et al. (2013) reported that dietary $\beta$-glucan positive effects on intestinal villi length and density of carp. These effects might be contributory factors to improve growth performance. Kühlwein et al. (2014) suggested that addition of $\beta$-glucan to mirror carp diet improved performance without effects on carcass body composition intestinal histo-morphology or the hemato-immunological parameters. Selim and Reda (2015) found that dietary supplementation of a combination of $\beta$ - glucan and MOS at 1.5 and $3 \mathrm{~g} / \mathrm{kg}$ feed improved growth performance and feed utilization in Nile Tilapia and the best growth and feed utilization were observed with group fed on $3 \mathrm{~g}$ prebiotic/kg feed. Soares et al. (2017) found that supplementation of $0.1 \%$ combined of Glucan and MOS produced from yeast, to juvenile pacu (Piaractus mesopotamicus) diet enhanced body weight gain, feed and protein efficiency compared to the control diet. Abu-Elala et al. (2018) reported that dietary addition of $\beta$-glucan and mannan oligosaccharide to Nile tilapia diet at 0.1 or $0.2 \%$ significantly increased growth parameters $(\mathrm{P} \leq 0.05)$ white blood cell count, total protein, and globulin level.

Table 1: Growth performance of Nile tilapia fed the experimental diets

\begin{tabular}{lcccc}
\hline Item & Initial Weight $(\mathbf{g})$ & Final Weight $(\mathbf{g})$ & Weight gain $\mathbf{( g )}$ & Specific growth rate \\
\hline Control & 4.21 & $12.47^{\mathrm{b}}$ & $8.25^{\mathrm{b}}$ & $1.94^{\mathrm{b}}$ \\
$\mathbf{2} \mathbf{~ g / k g ~ p r e b i o t i c ~}$ & 4.20 & $13.51^{\mathrm{a}}$ & $9.31^{\mathrm{a}}$ & $2.09^{\mathrm{a}}$ \\
$\mathbf{4} \mathbf{~ g / k g ~ p r e b i o t i c ~}$ & 4.23 & $13.38^{\mathrm{a}}$ & $9.15^{\mathrm{a}}$ & $2.06^{\mathrm{a}}$ \\
$\mathbf{6}$ g/kg prebiotic & 4.19 & $13.59^{\mathrm{a}}$ & $9.40^{\mathrm{a}}$ & $2.10^{\mathrm{a}}$ \\
$\mathbf{S E}$ of means & \pm 0.02 & \pm 0.16 & \pm 0.016 & \pm 0.02 \\
Significances & $\mathrm{NS}$ & $* *$ & $*$ & $*$ \\
\hline
\end{tabular}

Means designated with the same letter within the same column are not significantly different at 0.05 level of probability, ${ }^{*}:(\mathrm{p}<0.01),{ }^{*}:(\mathrm{p}<0.05)$, NS: Not significant $(\mathrm{P}>0.05)$.

Table 2: Feed utilization of Nile tilapia fed the experimental diets

\begin{tabular}{lccccc}
\hline Item & FI $(\mathbf{g})$ & FCR & PER & PPV & ER \\
\hline Control & 15.09 & $1.83^{\mathrm{a}}$ & $1.80^{\mathrm{b}}$ & $22.66^{\mathrm{b}}$ & $23.61^{\mathrm{b}}$ \\
$\mathbf{2}$ g/kg prebiotic & 15.69 & $1.69^{\mathrm{b}}$ & $1.96^{\mathrm{a}}$ & $27.10^{\mathrm{a}}$ & $26.97^{\mathrm{a}}$ \\
$\mathbf{4} \mathbf{g} / \mathbf{k g}$ prebiotic & 15.55 & $1.70^{\mathrm{b}}$ & $1.94^{\mathrm{a}}$ & $25.54^{\mathrm{a}}$ & $26.47^{\mathrm{a}}$ \\
$\mathbf{6}$ g/kg prebiotic & 15.73 & $1.67^{\mathrm{b}}$ & $1.97^{\mathrm{a}}$ & $26.08^{\mathrm{a}}$ & $27.08^{\mathrm{a}}$ \\
SE of means & \pm 0.14 & \pm 0.02 & \pm 0.02 & \pm 0.85 & \pm 0.71 \\
Significances & $\mathrm{NS}$ & $* *$ & $*$ & $* *$ & $*$ \\
\hline
\end{tabular}

Means designated with the same letter within the same column are not significantly different at 0.05 level of probability, **: $(\mathrm{p}<0.01),{ }^{*}:(\mathrm{p}<0.05)$, NS: Not significant $(\mathrm{P}>0.05)$.

Whereas: Feed intake (FI), Feed conversion ratio (FCR), Protein efficiency ratio (PER), Protein productive value (PPV), Energy Retention (ER). 
Table 3: Body composition of Nile tilapia fed the experimental diets.

\begin{tabular}{lcccc}
\hline Item & DM & Crude Protein & Ether Extract & Ash \\
\hline Initial & 22.11 & 53.70 & 16.20 & 14.83 \\
Control & 24.68 & 49.94 & 32.33 & 10.21 \\
$\mathbf{2}$ g/kg prebiotic & 26.09 & 50.84 & 31.57 & 10.42 \\
$\mathbf{4}$ g/kg prebiotic & 25.99 & 49.20 & 32.10 & 10.28 \\
$\mathbf{6}$ g/kg prebiotic & 26.10 & 48.98 & 32.54 & 9.95 \\
SE of means & \pm 0.30 & \pm 0.82 & \pm 0.89 & \pm 0.25 \\
Significances & NS & NS & NS & NS \\
\hline
\end{tabular}

Means designated with the same letter within the same column are not significantly different at 0.05 level of probability, NS: Not significant $(\mathrm{P}>0.05)$.

\section{Conclusions}

It can be concluded that the use of prebiotic (MOS and $\beta$-glucan) at the levels examined is capable of affecting the growth performances of fish. Feeding of Nile tilapia fingerlings on feeds with an addition of the MOS and $\beta$-glucan improved growth performance and feed utilization. The perfect addition of the prebiotic (MOS and $\beta$-glucan) in the fish diet is $2 \mathrm{~g} / \mathrm{kg}$ feed. Further studies are needed to investigate the underlying mechanistic pathways behind these findings, and explore other efficient nutritional strategies to improve growth performance and feed utilization of Nile tilapia fish in eco-friendly production system.

\section{References}

Abo-State, H.A. and A.M. Tahoun, 2017. The positive contributions of probiotic supplementation and artificial substrate to growth performance, feed utilization of Nile tilapia. Egyptian Journal of Nutrition and Feeds, 20 (1): 125-136.

Abo-State, H.A., M.M. El-Monairy, Y.A. Hammouda and M.Y. Elgendy, 2017. Effect of a phytogenic feed additive on the growth performance and susceptibility of Oreochromis niloticus to Aeromonas hydrophila. Journal of Fisheries and Aquatic Science, 12 (3):141-148.

Abu-Elala, N.M., N.A.Younis, H.O. Abu-Bakr, N.M. Ragaa, L.L. Borges, and M.A. Bonato, 2018. Efficacy of dietary yeast cell wall supplementation on the nutrition and immune response of Nile tilapia. The Egyptian Journal of Aquatic Research, 44: 4333-4341.

Al-Faragi, J.K., 2014. The efficacy of prebiotic ( $\beta$-glucan) as a feed additive against toxicity of aflatoxin B1 in common carp, Cyprinus carpio L. J. Aquac. Res. Dev. 5: 4.

Andrews, S.R., N.P. Sahu, A.K. Pal, and S. Kumar, 2009. Haematological modulation and growth of Labeo rohita fingerlings: effect of dietary mannan oligosaccharide, yeast extract, protein hydrolysate and chlorella. Aquaculture Research, 41:61-69.

Anguiano, M., C. Pohlenz, A. Buentello, and D.M. Gatlin, 2013. The effects of prebiotics on the digestive enzymes and gut histomorphology of red drum (Sciaenops ocellatus) and hybrid striped bass (Morone chrysops $\times$ M. saxatilis). British Journal of Nutrition, 109 (4): 623-629.

AOAC., 2006. Association of official analytical chemists official methods of analysis, AOAC. $18^{\text {th }}$ edition, Arlington, Virginia, USA.

Apperbossard, E., A. Feneuil, A. Wagner and F. Respondek, 2013. Use of vital wheat gluten in aquaculture feeds. Aquatic Biosystems, 9 (1): 21.

Azeredo, R., M. Machado, E. Kreuz, S. Wuertz, A. Oliva-Teles, P. Enes and B. Costas, 2017. The European seabass (Dicentrarchus labrax) innate immunity and gut health are modulated by dietary plant-protein inclusion and prebiotic supplementation. Fish and Shellfish Immunology, 60: 78-87.

Brogden, G., T. Krimmling, M. Adamek, H.Y. Naim, D. Steinhagen, G. von Brogden, M. von Köckritz-Blickwede, M. Adamek, F. Reuner, V. Jung Schroers, H.Y. Naim, and D. Steinhagen, 2012. $\beta$-Glucan protects neutrophil extracellular traps against degradation by Aeromonas hydrophila in carp (Cyprinus carpio). Fish Shellfish Immunol., 33: 1060-1064. 
Cechim, F.E., A.A. Signor, V.P. Cividanes, F.B. Sales, T.F. Da Silva, R.M. Dias Viana and R.Y. Sado, 2012. Prebiotic (mannanoligosaccharide-MOS) in fish nutrition: effects on Nile-tilapia Oreochromis niloticus performance. Boletim de Indústria Animal, 69:8.

Cerezuela, R., M. Fumanal, S.T. Tapia-Paniagua, J. Meseguer, M.A. Morinigo, and M.A. Esteban, 2013a. Changes in intestinal morphology and microbiota caused by dietary administration of inulin and Bacillus subtilis in gilthead sea bream (Sparus aurata L.) specimens. Fish Shellfish Immunology, 34: 1063-1070.

Cerezuela, R., J. Meseguer, and M.A. Esteban. 2013b. Effects of dietary inulin, Bacillus subtilis and microalgae on intestinal gene expression in gilthead seabream (Sparus aurata L.). Fish Shellfish Immunology, 134: 843-848.

Dawood, M.A.O. and S. Koshio, 2016. Recent advances in the role of probiotics and prebiotics in carp aquaculture: A review. Aquaculture, 454 (28): 243-251.

Dobšíková, R., J. Blahová, I. Mikulíková, H. Modrá, E. Prášková, Z. Svobodová, M. Škorič, J. Jarkovský and A. Siwicki, 2013. The effect of oyster mushroom $\beta-1.3 / 1.6-D$-glucan and oxytetracycline antibiotic on biometrical, haematological, biochemical, and immunological indices, and histopathological changes in common carp (Cyprinus carpio L.). Fish Shellfish Immunol, 35: 1813-1823.

Duncan, D., 1955. Multiple range tests and multiple F tests. Biometrics, 11: 1-42.

Ebrahimi, G.H., H. Ouraji, M.K. Khalesi, M. Sudagar, A. Barari, M. Zarei Dangesaraki and K.H. Jani Khalili, 2012. Effects of a prebiotic, Immunogen $\AA$, on feed utilization, body composition, immunity and resistance to Aeromonas hydrophila infection in the common carp Cyprinus carpio (Linnaeus) fingerlings. J. Anim. Physiol. Anim. Nutr., 96: 591-599.

Falco, A., J.J. Miest, N. Pionnier, D. Pietretti, M. Forlenza, G.F. Wiegertjes and D. Hoole, 2014. $\beta$ Glucan-supplemented diets increase poly(I:C)-induced gene expression of $\mathrm{Mx}$, possibly via Tlr3-mediated recognition mechanism in common carp (Cyprinus carpio). Fish Shellfish Immunol., 36: 494-502.

Fountoulaki, E., M. N. Alexis, I. Nengas and B. Venou, 2005. Effect of diet composition on nutrient digestibility and digestive enzyme levels of gilthead sea bream (Sparus aurata L.). Aquaculture Research, 36 (13): 1243-1251.

Ganguly, S. and A. Prasad, 2012. Microflora in fish digestive tract plays significant role in digestion and metabolism: A review. Rev. Fish Biol. Fish., 22:11-16.

Ganguly, S., K.C. Dora, S. Sarkar and S. Chowdhury, 2013. Supplementation of prebiotics in fish feed: A review, Rev. Fish. Biol. Fisher., 23:195-199.

Gatlin D. and P. Li, 2004. Dietary supplementation of prebotics for health management of hybrid striped bass Morone chrysops x M. saxatilis. Aqua Feeds Formul. Beyond., 1(4):19-21.

Geraylou, Z., C. Souffreau, E. Rurangwa, L. De Meester, C. M. Courtin, J.A.Delcour, J. Buyse, and F. Ollevier. 2013. Effects of dietary arabinoxylan oligosaccharides (AXOS) and endogenous probiotics on the growth performance, non-specific immunity and gut microbiota of juvenile Siberian sturgeon (Acipenser baerii). Fish Shellfish Immunol. 35 (3):766-775.

Gibson, G.R., and M.B. Roberfroid, 2004. Dietary modulation of the human colonic microbiota: Introducing the concept of prebiotics. Journal of Nutrition, 17 (2): 259-275.

Grisdale-Helland, B., S.J. Helland and D.M. Gatlin, 2008. The effects of dietary supplementation with mannanoligosaccharide, fructooligosaccharide or galactooligosaccharide on the growth and feed utilization of Atlantic salmon (Salmo salar). Aquaculture, 283 (1): 163-167.

Gu, M., H. Ma, K. Mai, W. Zhang, N. Bai and X. Wang, 2011. Effects of dietary $\beta$-glucan, mannan oligosaccharide and their combinations on growth performance, immunity and resistance against Vibrio splendidus of sea cucumber, Apostichopus japonicus. Fish Shellfish Immunol., 31(2): 303-309.

Guardiola, F.A., C. Porcino, R. Cerezuela, A. Cuesta, C. Faggio, and M.A. Esteban, 2016. Impact of date palm fruits extracts and probiotic enriched diet on antioxidant status, innate immune response and immune-related gene expression of European seabass (Dicentrarchus labrax), Fish. Shellfish Immunol., 52: 298-308. 
Guerreiro, I., A. Couto, M. Machado, C. Castro, P. Pousão-Ferreira, A. Oliva-Teles, and P. Enes, 2016. Prebiotics effect on immune and hepatic oxidative status and gut morphology of white sea bream (Diplodus sargus), Fish. Shellfish Immunology, 50: 168-174.

Guerreiro, I., C. R. Serra, P. Pousão-Ferreira, A. Oliva-Teles and P. Enes, 2018. Prebiotics effect on growth performance, hepatic intermediary metabolism, gut microbiota and digestive enzymes of White Sea bream (Diplodus sargus). Aquaculture Nutrition, 24 (1): 153-163.

Gültepe, N., S. Salnur, B. Hoşsu and O. Hisar, 2011. Dietary supplementation with Mannanoligosaccharides (MOS) from Bio-Mos enhances growth parameters and digestive capacity of gilthead sea bream (Sparus aurata). Aquaculture Nutrition, 17(5): 482-487.

Hoseinifar, S.H., M. Khalili, H.K. Rostami and M.A. Esteban, 2013. Dietary galactooligosaccharide affects intestinal microbiota, stress resistance, and performance of Caspian roach (Rutilus rutilus) fry. Fish \& Shellfish Immunology, 35(5): 1416-1420.

Hoseinifar, S.H., M.Á. Esteban, A. Cuesta and Y.Z. Sun, 2015. Prebiotics and fish immune response: A review of current knowledge and future perspectives. Reviews in Fisheries Science, 23 (4): 315-328.

Hoseinifar, S.H., Y.Z. Sun, and C.M. Caipang, 2017. Short-chain fatty acids as feed supplements for sustainable aquaculture: An updated view. Aquaculture Research, 48 (4): 1380-1391.

Hu, X., Yang, Y.Y. Yan, C.X. Zhang, J.D. Ye, K.L. Lu, and Y.Z. Sun, 2019. Effects of fructooligosaccharide on growth, immunity and intestinal microbiota of shrimp (Litopenaeus vannamei) fed diets with fish meal partially replaced by soybean meal. Aquaculture Nutrition, 25(1): 194-204.

Jung-Schroers, V., M. Adamek A. Jung S. Harris Ö.-S. Dóza A. Baumer D. Steinhagen, 2016. Feeding of $\beta-1,3 / 1,6$-glucan increases the diversity of the intestinal microflora of carp (Cyprinus carpio). Aquaculture Nutrition, 22: 1026-1039.

Kesarcodi-Watson, A., H. Kaspar, M.J. Lategan, and L. Gibson, 2008. Probiotics in aquaculture: The need, principles and mechanisms of action and screening processes, Aquacult., 274: 1-14.

Kühlwein, H., M.J. Emery, M.D. Rawling, G.M. Harper, D.L. Merrifield and S.J. Davies, 2013. Effects of a dietary $\beta-(1,3)(1,6)$-D-glucan supplementation on intestinal microbial communities and intestinal ultrastructure of mirror carp (Cyprinus carpio L.). J. Appl. Microbiol. 115: 1091-1106.

Kühlwein, H., D.L. Merrifield, M.D. Rawling, A.D. Foey and S.J. Davies, 2014. Effects of dietary $\beta$ $(1,3)(1,6)-D-g l u c a n$ supplementation on growth performance, intestinal morphology and haemato-immunological profile of mirror carp (Cyprinus carpio L.). J. Anim. Physiol. Anim. Nutr., 98: 279-289.

Kumar, P., K. Jain, P. Sardar, M. Jayant, and N. Tok, 2018. Effect of dietary synbiotic on growth performance, body composition, digestive enzyme activity and gut microbiota in Cirrhinus mrigala (Ham.) fingerlings. Aquaculture Nutrition, 24 (3): 921-929.

Mazurkiewiez, J., A. Przybył and J. Golski, 2008. Usability of Fermacto prebiotic in feeds for common carp (Cyprinus carpio L.) fry. Nauka. Przyr. Technol., 2 (3):15.

Mehdi, Y. and S.A. Mojtaba, 2009. A review of the use of prebiotic in aquaculture for fish and shrimp. African Journal of Biotechnology, 8 (25): 7313-7318.

Merrifield, D.L., A. Dimitroglou, A. Foey, S.J. Davies, R.T. M.Baker, J. Bøgwald, and E. Ringø, 2010. The current status and future focus of probiotic and prebiotic applications for salmonids. Aquaculture, 302 (1-2): 1-18.

Mohsen, S.H., A. Zaghlol, N.F. Abd El-Hakim, M. El Nawsany and H.A. Abo- State, 2016. Effect of different growth promoters on growth performance, feed utilization and body composition of Common carp (Cyprinus carpio). Journal of Fisheries and Aquatic Science, 11(5): 370-377.

Munir, M.B., R. Hashim, M.S.A. Manaf and S.A.M. Nor, 2016. Dietary prebiotics and probiotics influence the growth performance, feed utilisation and body indices of snakehead (Channa striata) fingerlings. Tropical Life Sciences Research, 27(2): 111-125.

Ringø, E., R.E. Olsen, T.Ø. Gifstad, R.A. Dalmo, H. Amlund, and G.I. Hemre, 2010. Prebiotics in aquaculture: a review, Aquacult. Nutr., 16: 117-136. 
Ringø, E., A. Dimitroglou, S.H. Hoseinifar and S.J. Davies, 2014. Prebiotics in finfish: an update. In: D., Merrifield, E., Ringø (Eds.), Aquaculture Nutrition: Gut Health, Probiotics and Prebiotics (pp. 360-400). Oxford, UK: Wiley-Blackwell Publishing.

Ringø, E., Z. Zhou, J.G. Vecino, S. Wadsworth, J. Romero, Å. Krogdahl and S. Davies, 2016. Effect of dietary components on the gut microbiota of aquatic animals. A never-ending story? Aquaculture Nutrition, 22(2): 219-282.

Romero, J., E. Ringø and D.L. Merrifield, 2014. The gut microbiota of fish. In: D., Merrifield, E., Ringø (Eds.), Aquaculture Nutrition: Gut Health, Probiotics and Prebiotics (pp. 75-100). Oxford, UK: Wiley-Blackwell Publishing.

Salem, M., M.M. Gaber, M.A.D. Zaki and A.A. Nour, 2016. Effects of dietary mannan oligosaccharides on growth, body composition and intestine of the sea bass (Dicentrarchus labrax L.). Aquaculture Research, 47 (11): 3516-3525.

Selim, K.M. and R.M. Reda, 2015. Beta-glucans and mannan oligosaccharides enhance growth and immunity in Nile tilapia. North American Journal of Aquaculture, 77: 22-30.

Soares, M.P., F.C. Oliveira, I.L. Cardoso, E.C. Urbinati, C. Meldau de Campos and H. Hisano, 2017. Glucan-MOS ${ }^{\circledR}$ improved growth and innate immunity in pacu stressed and experimentally infected with Aeromonas hydrophila. Fish Shellfish Immunol., 73:133-140.

Soleimani, N., S.H. Hoseinifar, D.L. Merrifield, M. Barati, and Z.H. Abadi, 2012. Dietary supplementation of fructooligosaccharide (FOS) improves the innate immune response, stress resistance, digestive enzyme activities and growth performance of Caspian roach (Rutilus rutilus) fry. Fish \& Shellfish Immunology, 32 (2): 316-321.

SPSS, 2007. Statistical Package for Social Science (for Windows). Release 16 copyright, SPSS Inc., Chicago, USA.

Staykov, Y., P. Spring, S. Denev and J. Sweetman, 2007. Effect of a mannan oligosaccharide on the growth performance and immune status of rainbow trout (Oncorhynchus mykiss). Aquaculture International 15: 153-161.

Talpur, A.D., M.B. Munir, M. Anna and R. Hashim, 2014. Dietary probiotics and prebiotics improved food acceptability, growth performance, haematology and immunological parameters and disease resistance against Aeromonas hydrophila in snakehead (Channa striata) fingerlings. Aquaculture, 427: 14-20.

Torrecillas, S., A. Makol, M.B. Betancor, D. Montero, M.J. Caballero and J. Sweetman, 2013. Enhanced intestinal epithelial barrier health status on European sea bass (Dicentrarchus labrax) fed mannan oligosaccharides. Fish Shellfish Immunol., 34: 1485-1495.

Torrecillas, S., D. Montero and M. Izquierdo, 2014. Improved health and growth of fish fedmannan oligosaccharides: potential mode of action. Fish Shellfish Immunol., 36, 525-544.

Wang, C.Y. and Z.B. Li 2020. Growth performance, digestive enzyme activity and immune response of Japanese sea bass, Lateolabrax japonicus fed with fructooligosaccharide. Aquaculture Nutrition, 26: 296-305.

Wu, Y., W.B. Liu, H.Y. Li, W.N. Xu, J.X. He, X.F. Li, and G.Z. Jiang, 2013. Effects of dietary supplementation of fructooligosaccharide on growth performance, body composition, intestinal enzymes activities and histology of blunt snout bream (Megalobrama amblycephala) fingerlings. Aquaculture Nutrition, 19(6): 886-894.

Ye, J.D., K. Wang, F.D. Li, and Y.Z. Sun, 2011. Single or combined effects of fructo- and mannan oligosaccharide supplements and Bacillus clausii on the growth, feed utilization, body composition, digestive enzyme activity, innate immune response and lipid metabolism of the Japanese flounder Paralichth. Aquaculture Nutrition, 17 (4): e902-e911.

Yousefian, M. and M.S. Amiri, 2009. A review of the use of prebiotic in aquaculture for fish and shrimp. African Journal of Biotechnology, 8: 7313-7318.

Zhou, Q.C., J.A. Buentello and D.M. Gatlin, 2010. Effect of dietary prebiotics on growth performance, immune response and intestinal morphology of red drum (Sciaenop socellatus). Aquaculture, 309: 253-257. 